DOI $10.31489 / 2020 \mathrm{Ec} 3 / 73-84$

JEL A23

UDC 338.46

\author{
A.S. Narynbayeva ${ }^{1, *}$, T.S. Korotkova ${ }^{2}$, Z. Simanaviciene ${ }^{3}$ \\ ${ }^{1,2}$ Innovative University of Eurasia,Kazakhstan, ${ }^{3}$ Kaunas University of Technology, Lithuania \\ ${ }^{1}$ narynbaeva@mail.ru, ${ }^{2}$ ktctania@mail.ru, ${ }^{3}$ zaneta.simanaviciene@ktu.it \\ ${ }^{1}$ http://orcid.org/0000-0002-6700-2030, ${ }^{2}$ http://orcid.org/0000-0002-3767-9040, \\ ${ }^{3}$ http://orcid.org/0000-0001-6008-2405 \\ ${ }^{1}$ Scopus AuthorID: 57195918317, ${ }^{3}$ Scopus Author ID: 23490464300
}

\title{
Current trends in the development of business-education in Kazakhstan (experience and challenges)
}

\begin{abstract}
Object: The purpose of the research is to investigate global trends in business education, analyze the development of the business education system in the country, evaluate its current state, identification of factors that hinder the development of the domestic business education system, identification of existing problems and disadvantages, and suggestion of solutions to these problems.

Methods: system, functional and statistical analyses, complex and historical approaches for studying the development of business education.

Results: The results revealed that the system of business education in Kazakhstan has developed and is currently at the stage of development. In the context of a changing business environment and high competition in the domestic market of business education for the implementation of management personnel training programs, the need to investigate and take into account the needs and interests of employers, business schools, and program participants themselves is becoming increasingly relevant. This issue is considered in the research on the example of one of the promising direction of training of professional managers of "Master of business administration" (MBA) program.

Conclusions: Based on the analysis of Kazakhstan and foreign sources, made research it is analyzed the latest developments of international business schools and the degree of their implementation in domestic practice, as well as offered suggestions for further improvement of the business education system, increasing the contribution of professional managers to ensuring sustainable development of the country's economy and social sphere.
\end{abstract}

Keywords: business education, MBA program, competitiveness, educational trajectories, entrepreneurial and managerial personnel, business school, human capital, generation Y.

\section{Introduction}

The competitiveness of any country's economy depends mainly on the level of human resource development, which is directly related to the education system. "Human capital", which decisively determines the economic potential of a country and, therefore, is the source of economic growth, creates education. The development of human capital is identified as the main priority for increasing the investment attractiveness of the region in the OECD report on the competitiveness of Central Asian economies. To solve this problem, it is recommended to eliminate the existing gaps in the training of qualified personnel, i.e., the discrepancy between the image structure and the requirements of the modern labor market (Drakh T.P. et al., 2020).

It should be emphasized that along with high-quality technological personnel, it is necessary to train and improve administrative and entrepreneurial personnel for the purpose of doing business. The basis for innovative economic formation is considered to be business itself, which, in turn, is considered to be more of a small and mediocre profitable business. In the Message of the President "Strategy Kazakhstan-2050" entrepreneurship is called "the driving force of the new economic policy"(Address by the President of the Republic of Kazakhstan, Leader of the Nation, N. Nazarbayev "Strategy Kazakhstan-2050": new political course of the established state", 2012). Modern conditions of doing business put forward new requirements for the competence of management personnel. The range of professional needs of entrepreneurs and managers in special knowledge of modern theory and practice of firm management is significantly expanding. Unfortunately, at the present time, the level of training and formation of entrepreneurial personnel in the state is considered unsatisfactory. The government demands to increase the overall level of business culture of entrepreneurs and the formation of entrepreneurial initiative.

\footnotetext{
* Corresponding author.

E-mail address: narynbaeva@mail.ru
} 
The purpose of this research is to study the current state of business education in the context of increasing integration and globalization of the world market. The tasks are set in the following way: to investigate innovative global trends in the development of business education, to determine its state in the Republic of Kazakhstan, to detect existing shortcomings and difficulties, as well as to transfer advice and instructions according to the improvement of this segment of education.

The article substantiates the concept of the need to improve legislation in the field of business education, the use of new approaches to the training and formation of high-quality administrative staff, as well as the use of elements of partnership with business and the country.

The significance of this work lies in the fact that as a result of consideration of existing documents and research, practical recommendations and proposals were developed to improve the concept of business education, the implementation of which will mainly improve the concept of training business and administrative personnel for the state economy.

\section{Literature Review}

Based on the analysis, the authors reviewed the work of such foreign researchers on the development of business education as Fong C.T., Pfeffer J., Ainsworth M., Morley C., Dougherty T.W., Dreher G.F., Whitely W., Schlegelmilch Bodo B., Thomas H. and others. The Influence of business schools on the development of the region is considered in the works of Arbaugh J.B. (Ben), Bento R., Hwang A., Montgomery D.Ramus C.A., Peggy K.and others. Various issues of development of business education system were considered in the works of domestic scientists: Alimbaev A.A., Bayserkeyev O.N., Kenzheguzin M.B., Kozhakhmetov A.B., Monobayeva A.I., Tayauova G.J., Shalbaev Sh.E. and others.

The literature review revealed that, despite the presence of scientific works of foreign and domestic authors, a long history of formation and development of institute of business education in the United States and Europe, still hasn't formed a perfect model of business school, not solved the problems which are of concern to the main stakeholders. The issues of development of business education requires more in-depth research, taking into account the process of turning business education into an independent sector of educational services, guided by market demand.

Today, the institute of business education is going through hard times. This was especially noticeable in the period of the economic crisis. Thus, graduates of MBA programs are reproached for not being able to foresee the crisis, i.e. the value of the institute of business education as such is questioned. In response to this criticism, business schools are adjusting their MBA programs, focusing on teaching the basics of socially responsible business, developing an entrepreneurial culture, and teaching risk assessment and strategies for dealing with the consequences of the crisis.

\section{Methods}

The sphere of domestic business education from the point of view of a detailed analysis of the main stakeholders (the state, employers, students, universities (business schools)) of this process has not yet become a priority object of special large-scale research. This research can be divided into three parts: the first a theoretical overview of the business education system; the second - practical experience of business schools around the world, and the third - an analysis of the development of business education and current problems in Kazakhstan.

Analytical reports and reports of international professional organizations, state program documents of the Republic of Kazakhstan constitute the theoretical and methodological basis of the article, they are used as materials containing tendencies and situations related to programs of additional professional education around the world and Kazakhstan, as well as works of scientists-economists of Kazakhstan, the CIS, near and far abroad on the problems of business education. The methodological basis of the research was based on system, functional and statistical analyses, as well as complex and historical approaches for investigation of the development of business education.

The information base of the study was the data of Committee of the RK on statistics, data of international rankings, Internet resources of domestic universities, the data periodicals. To research the impact of business schools in the regional economy, the authors used a systematic approach.

\section{Results}

The field of business education is responsible for collecting high - quality management personnel for business in developed countries, mainly through projects such as the MBA - Master of Business Administra- 
tion, DBA-Doctor of Business Administration, projects for the permanent creation and increase of the qualification of directors.

For Kazakhstan, business education is a relatively new concept that spread in the 90 s with the development of market mechanisms in the economy of the state. In a broad sense, business education refers to "educational activities aimed at the formation and development of administrative competencies (practically significant knowledge and professional skills) required for effective management of firms operating in market competition" (The State Program for the Development of Education of the Republic of Kazakhstan for 20112020, 2010).

International experience shows that the demand for administrative (business) education depends on the rate of economic growth. The higher the rate of business formation, the more companies need administrative staff. The study of the formation of business education abroad demonstrates that the methods, forms and content of business education are changing in connection with the changing economic climate. In response to changes in the labor market, business schools are revising their own training projects, introducing the latest training projects or topics, and integrating disciplines, making the academic process flexible and focused on meeting the needs of the labor market (Boatman Jazmine et al., 2011).

In Kazakhstan, the business education market is currently at the stage of emergence and development. Now it is shown by such large items as:

1) Business schools that implement projects in accordance with business Economics for postgraduate and higher education degrees;

2) independent training centers and consulting companies that implement short-term commercial development courses and offer consulting services;

3) training centers and corporate universities at large firms that make their own personnel in accordance with the profile of the company;

4) consulates of Russian and other foreign business schools and training companies in the Republic of Kazakhstan.

The main difference between business education and other sectors of the education system is considered to be the practical focus of training courses and projects, close cooperation of business schools and training and consulting firms with the real sector of the economy and high-class organizations of employers. The main problem of business educational institutions in Kazakhstan is considered to be the training of highly qualified professional managers, businessmen, entrepreneurs who can raise the economy of the state to the latest high-quality level.

The domestic market is in the process of formation, business schools compete with each other, corporate universities, training and consulting companies, thereby forming the right requests for business education. The world's top business schools competing for talented managers who want to get business education at the world level.

Recently, domestic business schools have received public recognition and successfully operate in the market. The development of a business education system is provided for by the growing demand for training and staff development. Business schools are aimed at the client in their work, therefore the quality of educational services in this area is much higher compared to other branches of education. To ensure good learning, some business schools are accredited by international accreditation agencies, such as CEEMAN, AACSB, AMBA International. Obtaining accreditation data for business schools is considered as confirmation of the high quality of provided services for marketing purposes within the country and in the CIS market.

In the process of international accreditation, the feedback issue is very relevant, since the business school is evaluated on the success of graduates. However, domestic business schools are not similar in the composition of students to the average world business school. We have many more entrepreneurs. In Western schools, about 5-7\% are entrepreneurs, the rest are officials and corporate managers. In Kazakhstan, in some groups, more than $50 \%$ are entrepreneurs. For global business schools, the key indicator is the growth of graduate wages. And the entrepreneur does not have a salary, this is not an indicator. Therefore, in the domestic practice, we analyze how the business and influence of graduates is growing (for example, they have received high positions in regions or national companies).

The report on positive changes in the field of training and management training of personnel in Kazakhstan shows that Kazakhstan has risen by 4 positions compared to last year and took the 55th place in the ranking of countries ' competitiveness in 2019 out of 140 countries. In accordance with the report on the world competitiveness of Kazakhstan, there is an improvement in many conditions, including the "level of 
training", according to which Kazakhstan has risen by 24 places (Detailed Report on the Competitiveness Ranking (GCI WEF), 2019).

As in the previous year, Kazakhstan's competitive advantages remain such factors as "labor market" 25 th place (increase by 5 positions) and "business dynamics" - 35th place (increase by 2 positions). In addition, the World Bank confirms the formation of the business climate in our country, as well as the indicators of the annual rating of the international economic company (IFC) Doing Business-2019. According to the results of this rating, Kazakhstan has risen to 21 places-from 49th to 28th place (Doing Business, 2019). A specific report recommends evaluating regulatory standards that promote or hinder business development throughout the business cycle, including company formation, business conduct, foreign trade, tax payment, and the degree of protection for traders.

Competition in the labor market forces managers with higher education to acquire continuously additional knowledge, skills and competencies. Demand for educational services generates supply, including from business schools. The MBA program, which trains management personnel for local companies, is becoming increasingly popular. MBA is an academic degree that is awarded to specialists who have received an education in the field of professional management. The MBA program allows effectively managing a team, seeing strategic perspectives and achieving established goals.

In Kazakhstan and other CIS countries, MBA programs are included in the block of programs that are additional to higher education (additional professional education), and in international practice are classified as Postgraduate programs designed for managers with work experience. MBA education takes place in business schools and, as a rule, it is as practice-oriented as possible. MBA programs are characterized by special complexity and direct connection with business and the state. Employers and business schools are directly involved in the training process. Listeners of MBA program deal with real-life cases (business situations in a particular company), attend seminars of renowned teachers and successful businessmen, do project work, take part in business simulations, trainings, etc.

For example, in Russia, according to the Russian association of business education, more than five thousand people are currently studied in MBA programs per year. This figure has been stable for 5-6 years, and has started to grow over the past two years. These are the most expensive and very difficult programs of the country's educational market. Russian business schools are mainly focused on the domestic market. This is both a virtue and a disadvantage. Training is much cheaper than the Western one, and the cases are filled with examples from the Russian reality. There are about 120 business schools and centers in Russia today. Compared to five thousand in the United States - this is certainly not much. Business education in the world, with all its flexibility, has its own strict standards and rigid value approaches. From this point of view, American, European, Chinese and Russian business schools teach similar products and implement similar methods and approaches.

Innovative trends in the development of global business education can be characterized by such properties as:

- transition from standardized education to client-oriented education;

- convergence of classical full-time education and online education;

- promotion of international standards for business project accreditation;

- global use of social networks and content in web resources (computers, mobile devices);

- popularity of evening and modular teaching configurations (Jerry Wind, 2015).

The market of MBA programs in Kazakhstan consists of more than 25 players, among which 15 are business schools of universities, 6 training and consulting companies, 2 corporate universities and 6 representative offices of foreign business schools. Most of them are concentrated in Almaty. Every year the number of educational institutions introducing MBA programs is growing. Compared to 2012, their number has almost quadrupled. According to the data of 2018, 3.8\% of students from the postgraduate education market as a whole studied in MBA programs in Kazakhstan. It is noteworthy that this type of education is preferred by men. So, of the total number of students studying for MBA, $55.2 \%$ are men and $44.8 \%$ are women. According to the data of 2018, the state basically doesn't finance education on the MBA, as evidenced by statistics. Students who enrolled at the expense of the state educational order are only $1 \%$ of the total market of MBA programs. At the expense of enterprises there are $8 \%$ students studied on MBA programs and $91 \%$ students study on MBA at the expense of purchasing from their own funds(Business education. Data of the Committee on Statistics of the Ministry of National Economy of the Republic of Kazakhstan, 2018).

Gradually, interest in business education is growing in Kazakhstan. Business schools started in a very weak market, and very few people applied to study in good business schools. First, now their number is 
growing, as is the growing attention of national and private corporations to education. Secondly, now almost $100 \%$ of people who come to business school for MBA programs have an idea about them from graduates. At the very beginning, it was, of course, difficult: most business schools had no accreditation, no reputation, and no graduates who would tell about the program, its pros and cons.

Now the number of programs (EMBA, etc.) has increased, the number of graduates of MBA programs has increased almost five times compared to 2012. The success of graduates of business schools, their demand, and experienced professors came to work on MBA programs.

Foreign professors do not move to live in Kazakhstan, their base remains in England, in America, in Europe, but they spend a lot of time in the country and, most importantly, they start writing business cases together with domestic business schools. This is a different type of relationship: not to bring the stars of world schools once a year, but to work with them constantly and for a long time.

Today, the country has a wide range of educational trajectories under the MBA program: Full-time MBA - full-time attendance; Part-time MBA - evening classes or modular programs, Distance MBA(allow students not to interrupt their business (management) activities for a long time), Mini-MBA - short-term training, Executive MBA - modular programs for executives with extensive experience of work (that is usually about 7 years) and business owners, Executive Education- short-term intensive programs for executives, business owners and functional managers (manager responsible for the work of one unit or industry).

The MBA and Executive MBA programs are similar in structure, but differ greatly in training methodology and group composition (table).

Table - Differences between MBA and EMBA

\begin{tabular}{|c|c|c|}
\hline Indicators & MBA & EMBA \\
\hline auditorium & entrepreneurs, middle manager & business owner, top managers of companies \\
\hline middle age & 30 years & 39 years \\
\hline $\begin{array}{l}\text { learning } \\
\text { objectives }\end{array}$ & $\begin{array}{l}\text { - } \quad \text { system understanding of business } \\
\text { - } \quad \text { career growth } \\
\text { - development of leadership potential } \\
\text { - } \quad \text { understanding your life and career path }\end{array}$ & $\begin{array}{l}\text { - } \text { strategic knowledge } \\
\text { - } \text { reload } \\
\text { - } \quad \text { innovation management } \\
\text { - } \text { making large-scaledecisions }\end{array}$ \\
\hline schedule & the program is designed for 18 or 24 months & the program is designed for 12 months \\
\hline description & \multicolumn{2}{|c|}{ between modules: homework, pre-reading, group projects } \\
\hline results & \multicolumn{2}{|c|}{$\begin{array}{ll} & \text { Entrepreneurs, business owners: } \\
\checkmark & \text { new business ideas, investment search; } \\
\checkmark & \text { development and scaling of existing business; } \\
\checkmark & \text { entering new markets. }\end{array}$} \\
\hline
\end{tabular}

In recent years, there has been a tendency towards highly specialized MBA programs. Although the classical MBA program is designed to train general managers who are able to work in companies of any business sphere (general management), in the last years MBA programs have begun to appear in various business areas of business or professions, such as finance or marketing. Also there are many narrower specializations, such as: for example, an MBA in logistics, an MBA in the field of HR, an MBA in energy, etc. However, in almost all such programs the first year of study consists of the general management disciplines, specialized subject starts only in the second year.

Education combining study in Kazakhstan and then continuing to study in other countries is still interesting. According to various sociological surveys, today, the following factors are most attractive in MBA education: the school's reputation + the availability of specialized programs + the opportunity to get a double degree (Kazakhstani and western). Different training formats are also in demand: modular training, distance courses, evening training, full-time training, intramural studies, weekend (3-day session: Friday, Saturday, Sunday - 1 time per month). There is a heightened interest in EMBA due to the fact that senior executives began to be guided by global experience in management and the latest technologies. It is important to remember that Kazakhstan's MBA programs have several distinctive features: an emphasis on domestic busi- 
ness; a mostly modular or evening training format; a lower cost compared to leading foreign MBA programs (on average, full-time MBA costs from $\$ 5000$ ).

However, MBA and EMBA programs have a high cost, however, in the world practice for many years there has been a system of grants for these programs. For any business school, the MBA program is the flagship program, it is mainly attended by young people (30-35\% owners, $65-70 \%$ corporate managers). As a rule, grants are given by companies and entrepreneurs for their employees. In the world practice, there are grants that cover from $20 \%$ to $100 \%$ of the cost of training. Therefore, the average competition for an MBA program abroad is more than three people per place - this is a significant factor for business education.

In Kazakhstan, there is also such a practice, for example, in Pavlodar, LLP "Pavlodar Petrochemical plant" issued more than 10 grants (100\% of the cost of training) for training under the MBA program for middle managers.

A reliable indicator of the level of the business school and its programs is the presence of joint MBA with well-known European business schools with the issuance of two diplomas. This is a de facto recognition that the quality of the programs of the domestic business school is comparable to the quality of the European partner school. Such joint programs of Kazakhstan and foreign business schools exist today.

For example, the MBA program of the Innovation University of Eurasia (further InEU) has been operating for more than 10 years, and has more than 200 graduates. Training is conducted in the following areas: "Corporate Management", "Leader". In 2015, InEU signed a cooperation agreement with the accredited international business school "Management and Marketing universal business school", Edinburgh, Scotland.

Two-degree studies provide the following opportunities:

- training under the MBA program of InEU together with the MMU business school - receiving two diplomas;

- training under the MBA program of InEU in parallel with a 1 or 2-year magistracy of InEU (in any specialty) - receiving two / three degrees;

- training in individual modules (attendance of several trainings) under the MBA program of InEU in parallel with a 1 or 2 year magistracy of InEU (in any specialty) - issuance of certificates for the completed training and there is transcript recording (Narynbayeva A.S., 2019).

MBA programs are usually attended by young people around 30 years old, Executive MBA programsthe average age is 39 years. There are shorter programs for beginners and experienced entrepreneurs.

At InEU, representatives of a large number of industries study in the MBA program, although, as in foreign business schools, the majority are representatives of the financial sector. These features allow undergraduates to work with classmates from different business fields, learn from each other, share experiences and open new horizons.

MBA contributes to the systematization of practical experience and accumulated knowledge, helps to find new opportunities to expand a business and increase company efficiency. One of the main advantages of an MBA, in addition to knowledge and skills, is networking. Ideally, studying on the MBA program, a student makes new business contacts that can be a catalyst for personal and career progression. Graduates get a real opportunity to improve their career and, respectively, increase their own value in the labor market. An important addition to learning is that students gain a full understanding of how to do business through the study of various disciplines.

How to choose a quality product from the set on the market? As a rule, MBA is estimated by two main indicators.

- Graduates income level. In developed countries, it is demand that determines the feasibility of investing in MBA, since the cost of a specialist in the market after obtaining a degree increases significantly. But in our country business is not very interested in such programs. The reason is poor awareness and dissatisfaction with the quality level of many Kazakhstan's MBA programs, which throw doubts on value of education. Thus, according to the Headhunter, $33 \%$ of the polled Kazakhstan specialists are dissatisfied with the quality of the domestic MBA and only $29 \%$ of the respondents are satisfied with it.

- International ratings and accreditation of programs, which indicate the quality of the provided services. Factors that influence the importance of business schools in foreign business education markets: the level of qualification is evaluated by prestigious international accreditations (the higher the status and the more authoritative the agency that accredited the program, the higher the MBA degree holder is evaluated), authoritative foreign ratings, and two-degree programs. There are many prestigious international accreditations and ratings in the world today, but most of the Kazakhstan's MBA programs aren't mentioned there. 
In particular, in the international ranking Eduniversal (France), that annually assesses 1000 business schools around the world (Shcherbakova O., 2016).

MBA is not an academic program where theory is taught, it is a program that provides practical knowledge applicable right here and right now. MBA aren't taught by academic teachers, traditional teaching approaches aren't used. MBA teachers are always experts with managerial experience of at least five years, which is supported by successful projects of business coach and work experience in various fields. The MBA uses an innovative approach to the content of the programs, to training, they are strictly focused on increasing the competencies of managers and contain the newest approaches to management.

The main method of teaching MBA is case study, i.e. case-based learning, i.e. each module tells a practical case from real life. In this way, the teacher engages the entire group in a discussion. After all, the MBA differs from other training in that you get $50 \%$ of the material from your classmates. All students have different production, life experience, different type of thinking, character, they look at the problem or solution of the problem in different ways-this enriches each other.

According to the results of the survey of the MBA Association conducted in 2016, the top 3 disciplines that MBA graduates consider to be with the minimum and maximum demand were identified: min (Economics, Operational management, Risk management) - 30\%; max (Strategic management, Finance and accounting, Leadership qualities) $-70 \%$.

The task of business schools is to form the content of the MBA program, which would correspond to modern tendencies in business and economy development; to provide the opportunity to transform the knowledge obtained in the course of training in the program into professional skills (hard skills, soft skills, including emotional intelligence); and to form a certain set of competencies that will help in successful business (Peggy K., 2007; Lublin J.S., 2016).

Kazakhstan has developed the State standard of the Republic of Kazakhstan on the basics of MBA, which includes: these are the required blocks of education - basic disciplines + scientific foundation of business + specialization. It is the specializations that differ in each business school that attract one or other MBA students with a focus on any specific direction.

\section{Discussions}

The goal of further development of any domestic business school is to make it a world-class school with a good reputation. This is facilitated by the accreditation process. However, on average, it takes 15 to 25 years for a business school to become visible. Therefore, it is also necessary for domestic business schools to participate in international competitions of MBA programs, products and cases, including joint ones with business schools in other countries. For example, every year the British newspaper "Financial Times" prepares a rating of MBA programs in the world. The financial Times rating of 100 leading business schools in Europe is one of the most authoritative and popular in the business environment.

Business school is a kind of transformation center associated with the generation of new ideas, with the growth of a new elite and with people for whom these ideas and values are very important. The scale of ideas for people entering the MBA program changes very quickly. Students come to school with questions "what to do with business?", and leave with the question "what to do with yourself and the country?". For them, these things are connected. This is not about money, but about projects for the whole country.

Students of the MBA program become part of the community and can come to the business school regularly to find partners and ideas, solve a problem, and this is much more important. For example, graduates of American business schools as the main result of their education point to getting into the community, for them it is an increase in social capital.

The MBA and EMBA programs are not so much about education as about new elites, which is a platform that can have a very serious impact on the situation in the country. A good education can be a giant lever, a multiplier of people with new ideas. Graduates leave in a different way - with a greater focus on their own development, on critical thinking, on the entrepreneurial spirit, on the search for opportunities. After training, some people give up their corporate careers and go into entrepreneurship. This is also a consequence of a change in mentality. Business education is also about freedom, about personal initiative, about entrepreneurship in the broad sense of the word - not making money, but creating some new entities, new relationships and values. This refers specifically to the change in the generational paradigm.

Graduates also become residents of the business school - this is a synergy of the school and graduates. They do not disappear from the field of view - every year, about $70 \%$ somehow return to business school for events, for re-training, act as mentors for students, do joint projects.

The overall concept of business education should be Lifelong learning. 
Analysts distinguish the following from the inclinations of the subsequent development of business education in Kazakhstan: training in basic MBA programs, and then additional education in various highly specialized short-term courses. The analysis showed that Executive MBA programs for senior executives and company owners will be in high demand. Due to the crisis, interest in corporate education has fallen, but after it ends, a surge of interest in such training is expected. Specialists expect the emergence of new specialized programs dictated by the trends of the time: management in the field of nanotechnology, innovation management, management of increased risks in investment activity, etc. After a while, the level of business education in Kazakhstan will increase, as well as the motivation of MBA students.

A characteristic feature of modern business education is its flexibility and maximum adaptability to the realities of the modern community and business. It tells how to deal with non-standard situations of Kazakhstan and Western business. In the concept of business education, projects should be regularly changed and improved. This applies to MBA programs and any other good management programs. The ecosystem is changing and the world is entering the digital economy. Therefore, for all management programs, and especially for MBA programs, the challenges are real and very tough. In 2020, according to statistics in Europe and the United States, more than 53\% of surveyed companies intend to hire MBA graduates to work in management, strategy and innovation, business development and consulting.

Just ten years ago, business school programs included courses such as: Managing Big Data, Digital Marketing (using and implementing new digital technologies in marketing), blockchain or distributed technologies, artificial intelligence, agile-strategy, or the impact of neuroscience on a leader's potential, Stress Management (managing yourself in moments of stress, as well as the ability to effectively overcome the consequences of negative situations), risk assessment, or sales effectiveness were simply not present. These terms themselves were unknown, and are now included in all serious MBA programs (Hwang A. et al., 2011; Schlegelmilch Bodo B., Thomas H., 2011).

In recent years, due to the active development of digital technologies and network communication technologies, as well as social networks, experts have noted the emergence of a "digital" type of thinking, which is more typical for generation Y, which already accounts for almost a third of the world's labor market, in 2020 it will become the dominant group, and in 2025, its share will be about $75 \%$ of the total employed population. Distance formats and interactive electronic programs are becoming more and more interesting.

Now there is an urgent question about online educational resources of MBA programs. Business schools operate more on-line. At the moment, the Massive Open Online Courses segment has grown rapidly, stabilized, and occupied a certain niche. However, the MBA program is characterized by a mixed approach: if the student wants to get only knowledge, then they can choose courses from the world's best schools online, but if they want to be inspired, find new ideas, get into a certain environment - then they can choose an off-line platform.

Representatives of domestic business schools also believe that a clean online format is the most favorable for short-term professional development and retraining programs, and MBA training-face-to-face communication with a business coach, group classes, discussion of complex issues and practical tasks, teamwork, case solving ("translated learning"), as well as mandatory interaction with other program participants (networking) (Home N., Strauss W., 2018; Simons J., 2016).

Therefore, interest to mixed MBA programs (Blended learning), combining the best of traditional (Fulltime and Part-time MBA) and online education (Distance MBA), will allow MBA programs to become personalized and more flexible in modern realities.

Nothing stands still; everything is in constant development and movement, including business. Anyone who moves along with these business processes can quickly understand what is happening and not only correctly apply this or that business matrix, but also create a new - its own. And, perhaps, this is one of the main goals of modern business education in Kazakhstan.

\section{Conclusion}

Thus, the analysis showed that along with positive trends in the system of domestic business education, there are problems that hinder its development, the most important of them are the following:

- the selection of students. People who do not have sufficient managerial experience are often accepted for MBA programs. When applying to a Western educational institution, the applicant's serious intentions must be supported by recommendations, essays, as well as several exams, but in Kazakhstan, the situation with competitive selection is quite different. Only in a few leading Russian business schools, this selection procedure is similar to established international standards; 
- in Kazakhstan, the MBA is still at the level of advanced training courses for middle managers. Of course, there are exceptions, but they still have little effect on the overall trend;

- the quality of domestic business education, including MBAs, varies greatly by school;

- the domestic MBA lacks a practical component. If the Western business education actually trains the Manager to solve standard management tasks, the Kazakh one only systematizes the existing practical experience and gives knowledge of the theory. Business school programs are not widely used cases of Kazakhstani companies (in recent years, this problem is being worked on, for example, the Association "Bolashak" published the first collection of Kazakhstan cases), as well as a small percentage of teachers-practitioners-on average 1: 10;

- uneven offers and services in the field of postgraduate business education in the regions of Kazakhstan;

- low level of state support for interaction between education and business;

- lack of mechanisms for motivating employers in cooperation with universities, business schools to develop professional competencies and learning outcomes; lack of mechanisms for forecasting demand for new professions, new competencies;

- Kazakhstan's business schools are not sufficiently integrated into the international educational space. Not all business schools have international accreditation;

- lack of serious research in the field of management/business education.

A big problem is the insufficient number of trained practical teachers. In business schools that work at universities, you can meet purely university teachers who don't moderate business discussions, but give lectures as students of the university. The reason for this phenomenon is usually a small school budget. This is significantly cheaper than inviting specialists from business, but it affects the quality, because only those who are engaged in it themselves can teach business, and not theorists with dissertations. However, if the teacher, is able to raise students for brainstorming, will give practical knowledge that they will immediately transfer to the business, this allows students to make a career leap and raise the profitability of their company.

Another serious disadvantage of Kazakhstani business schools is low admission requirements for incoming students (there are no entrance exams, which are practiced by western business schools, for example GMAT). Such approach contributes to the low quality of education and the diverse contingent on programs. In some business schools, you can get on the MBA program immediately after graduation of the university, resulting in an average age of students at 23-25 years.

A separate issue deserves the inadequate quality of many curricula and programs of business schools, the lack of emphasis on learning outcomes and management competencies of graduates. As is known, the MBA programs in Kazakhstan for a long time didn't have official status. State standards appeared only in 2006 , which negatively affected the quality of domestic business education. At the same time, there is an important tendency that will manifest itself increasingly in the next few years: the rejection of a staterecognized diploma in higher and postgraduate education. It should be noted that in Russia the issuance of state MBA diplomas was terminated in 2012. Masters of Business Administration receive a university degree - and this is a practice applied all over the world.

The results of the research conducted by the authors showed that the relationship of business schools with real business is fragmented, there is no system in working together, which leads to a gap between the level of training of students and the requirements of the labor market. The results of a survey of employers (members Of the Association of business women of Kazakhstan, managers of more than 30 companies located in the Pavlodar region), showed that, in General, employers are aware of the importance and need for close cooperation with business schools, as they are interested in quality training of specialists that meet modern market requirements. However, the main reason for the existing gap, the majority of respondents identified the lack of a mechanism for relationships and social partnership in order to provide both material and non-material motivation for all interested parties in joint cooperation.

In addition, the territorial plan focuses on uneven offers and services, $80 \%$ of business schools and educational and consulting firms in Almaty and Nur-Sultan. There are representative offices of business schools, such as the Almau center of education, KazEU. Also, the InEU training center in Pavlodar.

Almaty is distinguished by a high level of education in the areas of consulting and management in the field of science, as well as training in Western business schools. In a number of domestic business schools, a foreign diploma is also given (for example, in business schools there is a possibility to get diplomas from American, French, German, English business schools, but there is a nuance - only through joint pro- 
grams). Many potential students are deterred by the high cost of education, which, on the other hand, doesn't allow them to properly finance the activity of the schools themselves. All of the above problems significantly hinder and interrupt the development of the business education system (Monobayeva A.I., 2014).

In order to eliminate existing shortcomings and solve problems, we offer the following ways to solve the problems of business education development in Kazakhstan:

- The Ministry of education and science to implement a system of planning and modeling of market demand for professional personnel; to create effective mechanisms and permanent partnership procedures (state-business school (University)). Joint Work between universities, business schools, business and the country should be aimed primarily at such trends as: providing financial and economic support to higher education institutions, forming business incubators and resource centers, participation of the business sector in the process of creating an order for educational services, including targeted training of experts, a system of additional educational services, corporate MBA programs, advanced training courses.;

- change the entry conditions for the MBA program;

- for employers: participate in managing the content of the educational process through assistance in the Board of Trustees of business schools, research strategies, training projects and programs; participate in teaching in MBA programs, but also in the development and implementation of continuing education programs for business coaches;

- for business schools: regularly refresh the essence of business educational projects and adapt them to regularly changing circumstances in the labor market.

Implementation of these issues will provide the main conditions for the promotion of Kazakhstan's business education and its integration into the global educational space.

Therefore, the system of professional business education in Kazakhstan has both positive trends and difficulties. In order to solve the existing problems, all funds should be attracted, including municipal authorities, since the quality of business education ultimately determines the competitiveness of the state's economy; further economic growth is not feasible without well-trained and educated managers. The concept of business education is intended to play a major role in the creation and formation of labor resources, to become the basis for innovative transformations of society. The level of human capital in the country, and hence the competitiveness of the economy, will depend on the development of this area.

\section{References}

Biznes-obrazovanie [Business education]. Dannye Komiteta po statistike Ministerstva natsionalnoi ekonomiki RK [Data of the Committee on Statistics of the Ministry of National Economy of the Republic of Kazakhstan]. stat.gov.kz. Retrieved from http://stat.gov.kz [in Russian].

Boatman Jazmine, Wellins Rich, \& Selkovist, A. (2011). Global Leadership Forecast 2011. Bridgeville, PA: Development Dimensions International, 1-4.

Drakh, T.P., Salzhanova, Z.A., \& Vitrenko, A. (2020). The effectiveness analysis of the university-business interaction institutional mechanism and recommendations for its improvement. Bulletin of the Karaganda university. Economy series, 2(98), 32-41.

Hosudarstvennaia prohramma razvitiia obrazovaniia Respubliki Kazakhstan na 2011-2020 hody. Ofitsialnyi internetresurs Ministerstva obrazovaniia i nauki RK [The State Program for the Development of Education of the Republic of Kazakhstan for 2011-2020. The official web site of the Ministry of Education and Science of the Republic of Kazakhstan]. (2010). edu.gov.kz. Retrieved from http://www.edu.gov.kz[in Russian].

Home, N., \& Strauss, W. (2018). Millenials Rising: The Next Generation. Small Business and the City. https://doi.org/10.3138/9781442696501-014.

Hwang, A., Bento, R., \& Arbaugh, J.B. (2011). Post-MBA industry shifts: An investigation of career, educational and demographic factors. Career Development $592-615$. https://doi.org/10.1108/13620431111178344.

Jerry Wind (2015). Beyond Advertising: Creating Value Through All Customer Touchpoints. Wiley, 288.

Klaus Schwab (2018). The Global Competitiveness Report 2018. World Economic Forum, 671. weforum.org. Retrieved from https://www.weforum.org/reports/the-global-competitveness-report-2018.

Lublin, J.S. (2016). Companies Try a New Strategy: Empathy Training. The Wall Street Journal.wsj.com. Retrieved from https://www.wsj.com/articles/.

Monobayeva, A.I. (2014). Razvitiie biznes-obrazovaniia v Respublike Kazakhstan: problemy i puti resheniia [Development of business education in the Republic of Kazakhstan: problems and solutions]. Vestnik Kazakhskoho natsionalnoho univtrsiteta. Seriia Yekonomika [KazNU Journal. Economic series], 2 (102), 120-129 [in Russian].

Narynbayeva, A.S. (2019). Educational trajectories in the MBA program (experience of Innovative University of Eurasia). [Scientific and practical materials of the II world Congress in real and virtual mode "West-East: intersection of cultures"]. Yaponiyi, Kioto, Universitet Kioto Sanhe. Izdatelstvo: Tanaka Print, 537-543. 
Overview. (2019). Doing Business-2019. Training for Reform, 5.doingbusiness.org. Retrieved from https://www.doingbusiness.org/.

Peggy, K. (2007). The Hard Truth about Soft Skills. New York: Harper Collins Publishers. 205.r-5.org. Retrieved from http://www.r-5.org/files/books/.

Podrobnyi otchet o reitinhe konkurentosposobnosti (GIK VJeF) 2019 hoda [Detailed Report on the Competitiveness Ranking (GCI WEF) 2019]. csi.kz.Retrieved from https://csi.kz/news/09102019 [in Russian].

Schlegelmilch Bodo, B., \& Thomas, H. (2011). The MBA in 2020: will there still be one? Journal of management development, 5, 474-482.

Shcherbakova, O. (2016). MVA: est li svet v kontse tunnelia? [MBA: is there a light at the end of the tunnel?]. $n b . k z$. Retrieved from http://nb.kz/15761/ [in Russian].

Simons, J. (2016). Tomorrow's Business Leaders Learn How to Work with A. I. The Wall Street Journal. wsj.com. Retrieved from https://www.wsj.com/articles/.

Stratehiia "Kazakhstan - 2050". Novyi politicheskii kurs sostoiavshehosia hosudarstva. Poslanie Prezidenta Respubliki Kazakhstan — Lidera natsii N.A. Nazarbaeva narodu Kazakhstana ["Strategy Kazakhstan-2050": new political course of the established state". Address by the President of the Republic of Kazakhstan, Leader of the Nation, N.Nazarbayev]. (2012). adilet.zan.kz. Retrieved from http://adilet.zan.kz/rus/docs/K1200002050 [in Russian].

\section{А.С. Нарынбаева, Т.С. Короткова, Ж. Симанавичене \\ Қазақстандағы бизнес-білім беру дамуының қазіргі тенденциялары (тәжірибе және мәселелер)}

\section{Аңдатпа}

Maқcambl: Зерттеудің мақсаты бизнес-білім берудегі әлемдік трендтерді зерделеу, елдегі бизнес-білім беру жүйесінің дамуын талдау, оның қазіргі жай-күйін бағалау, отандық бизнес-білім беру жүйесінің дамуын тежейтін факторларды анықтау, бар мәселелер мен кемшіліктерді анықтау, осы мәселелерді шешу жолдарын ұсыну болып табылады.

Әдісі: жүйелік, функционалды және статистикалық талдау, бизнес-білімнің дамуын зерттеудің кешенді және тарихи тәсілдер қолданылған.

Қорытынды: Зерттеу нәтижелері Қазақстанның бизнес-білім беру жүйесі қалыптасқан және қазіргі уақытта және даму сатысында тұрғанын анықтады. Басқарушы кадрларды даярлау бағдарламаларын іске асыру үшін отандық бизнес-білім беру нарығындағы өзгермелі бизнес-орта және жоғары бәсекелестік жағдайында жұмыс берушілердің, бизнес-мектептердің және бағдарламаға қатысушылардың өздерінің қажеттіліктері мен мүдделерін зерделеу және есепке алу қажеттілігі үлкен өзектілікке ие болады. Жұмыста осы мәселе «Іскер әкімшілік шебері» (ІӘШ) бағдарламасының кәсіби менеджерлерін даярлаудың перспективалық бағыттарының бірі мысалында қарастырылған.

Тұжырымдама: Авторлар кәсіпкерлік және басқарушы кадрларды қалыптастырудағы және дамытудағы бизнес-мектептердің маңызды рөлі туралы қорытынды жасайды. Қазақстандық және шетелдік дереккөздерді талдау, жүргізілген зерттеу негізінде халықаралық бизнес-мектептердің соңғы әзірлемелері және оларды отандық тәжірибеге енгізу дәрежесі талданды, сондай-ақ бизнес-білім беру жүйесін одан әрі жетілдіру, ел экономикасы мен әлеуметтік саланың тұрақты дамуын қамтамасыз етуде кәсіби жетекшілердің үлесін арттыру жөнінде ұсыныстар берілді.

Kiлm сөздер: бизнес-білім, МВА бағдарламасы, бәсекеге қабілеттілік, білім беру траекториялары, кәсіпкерлік және басқару кадрлары, бизнес мектебі, адами капитал, ұрпақ Ү.

\section{А.С. Нарынбаева, Т.С. Короткова, Ж. Симанавичене}

\section{Современные тенденции развития бизнес-образования в Казахстане (опыт и проблемы)}

\section{Аннотация}

Цель: Целью исследования явилось изучение мировых трендов в бизнес-образовании, анализ появления и развития системы бизнес-образования в стране, оценка ее современного состояния, анализ основных субъектов бизнес-образования, выявление факторов, сдерживающих развитие отечественной системы бизнес-образования, определение имеющихся проблем и недостатков, предложение путей решения данных проблем.

Memodbl:системный, функциональный и статистический анализы, комплексный и исторический подходы для изучения развития бизнес-образования.

Результаты: Результаты исследования выявили, что система бизнес-образования Казахстана сложилась и в настоящее время находится на стадии становления и развития.В условиях меняющейся бизнес-среды и высокой конкуренции на отечественном рынке бизнес-образования для реализации программ подготовки управленческих кадров в бизнес-школах все большую актуальность приобретает необходимость изучения и учета потребностей и интересов работодателей, бизнес-школ и самих участников программ. В работе данный вопрос 
рассмотрен на примере одного из перспективных направлений подготовки профессиональных менеджеров программы «Мастер делового администрирования» (МВА).

Bblвoдbl:Авторами сделан вывод о важной роли бизнес-школ в формировании и развитии предпринимательских и управленческих кадров. На основе анализа казахстанских и зарубежных источников проанализированы последние разработки международных бизнес-школ и степень их внедрения в отечественную практику, а также даны предложения по дальнейшему совершенствованию системы бизнес-образования, увеличению вклада высококвалифицированных профессиональных руководителей в обеспечение устойчивого развития экономики страны и социальной сферы.

Ключевые слова:бизнес-образование, программа МВА, конкурентоспособность, образовательные траектории, предпринимательские и управленческие кадры, бизнес-школа, человеческий капитал, поколение Ү.

\section{References}

Boatman Jazmine. Global Leadership Forecast. Bridgeville / Jazmine Boatman, Rich Wellins, A Selkovist // PA: Development Dimensions International. - 2011. - C. 1-4.

Drakh T.P. The effectiveness analysis of the university-business interaction institutional mechanism and recommendations for its improvement / T.P. Drakh, Z.A. Salzhanova, A. Vitrenko // Bulletin of the Karaganda university.Economy series. — 2020. — № 2(98). - C. 32-41.

Home N. Millenials Rising: The Next Generation / N. Home, W. Strauss // Small Business and the City. — 2018. (https://doi.org/10.3138/9781442696501-014)

Hwang A. Post-MBA industry shifts: An investigation of career, educational and demographic factors / A. Hwang, R. Bento, J.B. Arbaugh // Career Development International. — 2011. — № 16(6). — C. 592-615. (https://doi.org/10.1108/13620431111178344)

Jerry Wind. Beyond Advertising: Creating Value Through All Customer Touchpoints / Wind Jerry // Wiley. — 2015. - C. 288.

Klaus Schwab. The Global Competitiveness Report 2018 / Schwab Klaus // World Economic Forum. — 2018. C. 671. - (https://www.weforum.org/reports/the-global-competitveness-report-2018)

Lublin J.S. Companies Try a New Strategy: Empathy Training / J.S. Lublin //The Wall Street Journal. — 2016. — (https://www.wsj.com/articles)

Overview. Doing Business-2019. (2019). Training for Reform. — № 5. — (https://www.doingbusiness.org/)

Peggy K. The Hard Truth about Soft Skills / K. Peggy // New York: Harper Collins Publishers. — 2007. (http://www.r-5.org/files/books/)

Schlegelmilch Bodo B. The MBA in 2020: will there still be one? / B. Schlegelmilch Bodo, H. Thomas // Journal of management development. — 2011. — № 5. - P. 474-482

Simons J. Tomorrow's Business Leaders Learn How to Work with A. I. / J. Simons // The Wall Street Journal. — 2016. — (https://www.wsj.com/articles/)

Бизнес-образование. Данные Комитета по статистике Министерства национальной экономики РК. (http://stat.gov.kz)

Государственная программа развития образования Республики Казахстан на 2011-2020 годы. Официальный интернет-ресурс Министерства образования и науки РК. — (http://www.edu.gov.kz)

Щербакова О. МВА: есть ли свет в конце туннеля? / О. Щербакова // Официальный интернет-ресурс. — 2016. - (http://nb.kz/15761/)

Монобаева А.И. Развитие бизнес-образования в Республике Казахстан: проблемы и пути решения / А.И. Монобаева // Вестн. Казах. нац. ун-та. Сер. экон. - 2014. — № 2 (102). — С. 120-129.

Narynbayeva, A.S. Educational trajectories in the MBA program (experience of Innovative University of Eurasia) / А.С. Нарынбаева // Научно-практические материалы II Всемир. конгр. в реальном и виртуальном режиме «Запад - Восток: пересечение культур». — Япония, Киото, Университет Киото Санге: Изд-во: «Тапака Print», 2019. - C. 537-543.

Подробный отчет о рейтинге конкурентоспособности (ГИК ВЭФ) 2019 года. (2019). Официальный интернетресурс Центр стратегических инициатив. — (https://csi.kz/news/09102019).

Послание Президента Республики Казахстан - Лидера нации Н.А. Назарбаева народу Казахстана. Стратегия «Казахстан - 2050»: Новый политический курс состоявшегося государства. (http://adilet.zan.kz/rus/docs/K1200002050). 